\title{
PELATIHAN PENGOLAHAN TEMPE MENJADI MINUMAN DAN TEPUNG TEMPE PADA TUTOR PAUD DI KECAMATAN MAKASAR JAKARTA TIMUR
}

\author{
Alsuhendra ${ }^{1)}$, Ridawati ${ }^{2)}$ \\ Jurusan IKK Fakultas Teknik Universitas Negeri Jakarta
}

\begin{abstract}
ABSTRAK
Kegiatan pengabdian kepada masyarakat ini bertujuan untuk meningkatkan pengetahuan dan keterampilan pengelola dan tutor PAUD di Kecamatan Makasar Jakarta Timur tentang pengolahan tempe menjadi minuman sari tempe dan tepung tempe. Kegiatan dilaksanakan di PAUD Kuntum Melati Kampung Makasar Jakarta Timur dengan melibatkan 23 orang sasaran. Metode yang digunakan dalam pelaksanaan kegiatan ini adalah penyuluhan interaktif antara narasumber dengan sasaran serta demonstrasi pengolahan tempe. Dari pelaksanaan kegiatan ini diketahui terjadi peningkatan pengetahuan sasaran tentang tempe dan produk olahannya, yaitu minuman sari tempe serta tepung tempe. Para pengelola dan tutor PAUD Kuntum Melati juga menyatakan tertarik untuk mengonsumsi dan memproduksi sendiri minuman sari tempe dan tepung tempe karena dipahami bahwa minuman tempe dan tepung tempe memiliki berbagai manfaat bagi kesehatan.
\end{abstract}

Kata Kunci : tempe, minuman sari tempe, tepung tempe, tutor, PAUD

\section{PENDAHULUAN}

\section{A. Analisis Situasi}

Salah satu bentuk lembaga pendidikan non formal yang banyak dikembangkan di Indonesia adalah Pusat Kegiatan Belajar Masyarakat (PKBM). Pusat Kegiatan Belajar Masyarakat telah menjadi tempat pem-belajaran berbagai macam pengetahuan dan keterampilan bagi masyarakat, sehingga keberadaan PKBM dirasakan masyarakat telah menjadi alternatif sumber pembelajaran, khususnya bagi masyarakat putus sekolah atau dengan tingkat ekonomi lemah.

Berbagai PKBM telah dikembangkan oleh pemerintah dan masyarakat (swasta), di antaranya terdapat di Kecamatan Makasar Jakarta Timur. Jenis kegiatan pembelajaran yang dilaksanakan pada PKBM di Kecamatan Makasar cukup beragam, termasuk kegiatan Pendidikan Anak Usia Dini (PAUD). Data pada tahun 2015 menunjukkan bahwa terdapat sekitar 45 lembaga PAUD negeri dan swasta di wilayah tersebut dengan jumlah guru sebanyak 205 orang serta total murid 2088 orang.

Kegiatan pembelajaran di PAUD harus dilakukan dengan prinsip menyenangkan dan dapat memelihara potensi anak, baik fisik maupun mental. Tutor memegang peran penting dalam mendidik anak karena tutor berperan sebagai pembimbing, pelatih, atau pendidik anak-anak.Untuk itu, tutor yang bertugas sebagai pelaksana kegiatan pem-belajaran harus memiliki pengetahuan dan keterampilan yang handal agar dapat mendidik anak-anak dengan baik dan sesuai dengan tahapan perkembangan usia anak.

Peningkatan pengetahuan dan keterampilan seorang tutor dapat dilakukan melalui pendidikan lanjut pada strata yang lebih tinggi, atau melalui sejumlah kegiatan pelatihan, baik yang diadakan oleh Suku Dinas Pendidikan Non Formal Informal (PNFI) atau lembaga lainnya. Salah satu pengetahuan dan keteram-pilan yang perlu dimiliki oleh tutor adalah pengetahuan dan keterampilan tentang makanan yang harus dikonsumsi oleh seorang anak usia dini. Hal ini didasarkan pada pentingnya memberikan makanan yang baik dan bergizi kepada anak usia dini agar anak-anak tersebut dapat tumbuh dan berkembang dengan sehat dan memiliki kecerdasan tinggi.

Pelatihan bagi tutor tentang pengolahan makanan yang baik penting dilakukan. Dengan pelatihan tersebut, tutor dapat menyebarluaskan 
pengetahuan dan keterampilan pengolahan makanan tersebut kepada anak-anak dan orang tua.Dalam hal ini, tutor adalah agen peubah dan agen pentransfer pengetahuan bagi masyarakat.

Berbagai bentuk pengolahan makanan dengan menggunakan teknologi tepat guna dapat disampaikan kepada para tutor, khususnya tutor yang mengajar pada PAUD di Kecamatan Makasar. Di antara teknologi tepat guna tersebut adalah pengolahan tempe menjadi minuman sari tempe dan tepung tempe.

Tempe merupakan salah satu jenis makanan yang mengandung gizi tinggi, karena kaya akan protein, vitamin, dan mineral. Meskipun memiliki kandungan gizi yang tinggi, tidak semua anak-anak menyukai tempe sebagai lauk. Oleh karena itu, pengolahan tempe menjadi minuman sari tempe diharapkan dapat meningkatkan kesukaan anak-anak terhadap tempe olahan dengan kandungan gizi yang juga tinggi. Minuman sari tempe dianggap sebagai produk diversifikasi pangan berbasis tempe.Sebagaimana tempe, minuman sari tempe memiliki kandungan gizi yang tinggi, bahkan dapat digunakan pula sebagai minuman antidiare.

Selain dijadikan minuman, tempe juga dapat diolah menjadi tepung yang selanjutnya diaplikasikan sebagai bahan untuk membuat berbagai produk olahan pangan. Proses pembuatan tepung tempe juga sederhana, sehingga dapat dilakukan dengan mudah oleh tutor dan masyarakat lainnya.

Pelatihan yang akan diberikan kepada tutor PAUD di Kecamatan Makasar ini tidak hanya bertujuan untuk meningkatkan pengetahuan dan keterampilan tutor, tetapi juga diharapkan dapat menjadi sumber pendapatan alternatif bagi tutor dan masyarakat sekitar. Dalam hal ini, tutor dan masyarakat dapat mengolah minuman sari tempe dan produk tempe lainnya, seperti tepung tempe menjadi produk dengan nilai ekonomi tinggi dan layak untuk dipasarkan.

\section{B. Permasalahan Mitra}

Lembaga penyelenggara kegiatan PAUD di Kecamatan Makasar Jakarta Timur perlu diberdayakan sebagai agen peubah untuk meningkatkan pengetahuan dan keterampilan masyarakat dalam berbagai bidang.Pelaku utama yang berperan sebagai agen peubah pada lembaga PAUD adalah tutor.

Tutor umumnya berasal dari masyarakat yang memiliki tingkat ekonomi menengah ke bawah, terutama tutor dengan status swasta. Selain memiliki pendapatan yang rendah, tutor juga kurang mengusai berbagai keterampilan yang dibutuhkan untuk mendukung tumbuh kembang anak usia dini, seperti keterampilan dalam mengolah makanan. Secara umum, permasalahan yang dijumpai pada tutor PAUD di Kecamatan Makasar adalah:

1) Rendahnya tingkat pendapatan dan status ekonomi tutor

2) Kurangnya kegiatan pelatihan bagi tutor dalam rangka meningkatkan pengetahuan dan keterampilan mengolah makanan

3) Kurangnya upaya untuk meningkatkan pendapatan tutor karena tidak adanya alternatif kegiatan bisnis yang dikembangkan oleh pengelola PKBM dengan melibatkan tutor sebagai pelaku bisnis

4) Terbatasnya tingkat pengetahuan dan keterampilan tutor dalam mengolah makanan yang berperan penting dalam mendukung tumbuh kembang anak usia dini

5) Kurangnya inisiatif tutor dan masyarakat dalam melakukan diversifikasi produk olahan makanan atau minuman.

\section{Solusi yang Ditawarkan}

Solusi yang ditawarkan untuk mengatasi berbagai permasalahan yang dihadapi oleh tutor dan masyarakat lainnya di Kecamatan Makasar Jakarta Timur adalah sebagai berikut:

1. Peningkatan pengetahuan tutor PAUD dan masyarakat di Kecamatan Makasar tentang manfaat tempe dan hasil olahannya.

2. Peningkatan keterampilan tutor PAUD dan masyarakat di Kecamatan Makasar dalam mengolah tempe menjadi minuman sari tempe dan tepung tempe yang memiliki nilai ekonomi tinggi.

3. Pemberian motivasi kepada tutor PAUD dan masyarakat di Kecamatan Makasar agar dapat membentuk dan mengem- 
dapat menjadi sumber pendapatan tambahan bagi keluarga.

\section{Luaran} adalah :

Luaran yang diharapkan dari kegiatan ini

1. Meningkatnya kualitas pengetahuan dan keterampilan tutor PAUD dan masyarakat di Kecamatan Makasar.

2. Meningkatnya partisipasi dan motivasi masyarakat dalam melakukan pengolah-an tempe menjadi minuman sari tempe dan tepung tempe yang berkhasiat bagi kesehatan anak usia dini.

\section{MATERI DAN METODE}

A. Tempat dan Waktu

Rencana, pelaksanaan, dan pembuatan laporan kegiatan pengabdian kepada masyarakat ini dilaksanakan di UNJ dari bulan Juni hingga Nopember 2015, sedangkan kegiatan pelatihan pembuatan minuman dan tepung tempe dilaksanakan di Balai RW 5 PAUD Kuntum Melati Jl. Usman Harun Kampung Makasar Jakarta Timur pada tanggal 29 September 2015.

\section{B. Khalayak Sasaran}

Kegiatan ini dilakukan dengan melibatkan sekitar 23 orang pengelola dan tutor PAUD Kuntum Melati yang menjadi sasaran kegiatan.

\section{Metode}

Peningkatan pengetahuan dan keterampilan sasaran dilakukan dengan metode penyuluhan interaktif dan demonstrasi pengolahan produk tempe. Dari pelaksanaan kegiatan ini terjadi peningkatan pengetahuan dan keterampilan sasaran tentang tempe serta produk minuman dan tepung tempe.

Langkah-langkah yang diambil dalam pelaksanaan kegiatan ini adalah:

1. Mengidentifikasi calon pengelola dan tutor PAUD yang akan dijadikan peserta.

2. Menyiapkan narasumber yang memberikan informasi dan pengetahuan tentang minuman sari tempe dan tepung tempe.

3. Menyiapkan instruktur untuk melatih sasaran dalam membuat minuman sari tempe dan tepung tempe.

4. Mengundang sasaran untuk mengikuti kegiatan pelatihan.

5. Melaksanakan kegiatan pelatihan.

6. Mengevaluasi pengetahuan dan motivasi sasaran tentang tempe dan produk minuman sari tempe serta tepung tempe. Evaluasi dilakukan dengan cara memberikan sejumlah pertanyaan tertulis kepada para sasaran. Salah satu aspek yang sangat menentukan keberhasilan evaluasi adalah rancangan evaluasi yang dikembangkan sebagai instrumen pengukuran keberhasilan dan pencapaian tujuan. Instrumen yang digunakan adalah angket yang berisi sejumlah pertanyaan.

\section{HASIL DAN PEMBAHASAN \\ A. Tingkat Pengetahuan Pengelola dan Tutor}

Penyuluhan merupakan salah satu cara yang dapat dilakukan untuk meningkatkan pengetahuan masyarakat. Dalam kegiatan ini, penyuluhan dilakukan untuk meningkatkan pengetahuan pengelola dan tutor PAUD Kuntum Melati Kampung Makasar Jakarta Timur tentang tempe dan produk olahannya.

Untuk mengetahui tingkat pengetahuan dasar pengelola dan tutor PAUD Kuntum Melati tentang tempe dan produk olahannya, sebelum penyuluhan diberikan, terlebih dahulu dilakukan penilaian tingkat pengetahuan sasaran melalui pengisian instrumen pre-test. Instrumen tersebut berisi 8 pertanyaan tentang materi dan harus dijawab oleh sasaran dengan jujur. Selanjutnya, untuk mengetahui efektivitas dari penyuluhan, setelah diberikan penyuluhan, kepada sasaran ditanyakan kembali 8 pertanyaan yang sama (post-test) guna mengetahui tingkat keterserapan materi peyuluhan oleh sasaran. Hasil dan pembahasan terhadap data pre- dan post-test disajikan di bawah ini. 


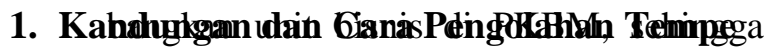

Tempe termasuk jenis makanan yang memiliki kualitas gizi baik, khususnya protein. Karena mengalami proses fermentasi, kedele yang menyusun tempe mengandung protein dengan daya cerna yang lebih tinggi dibandingkan dengan protein kedelai.

Di dalam instrumen pre-test dan post-test dinyatakan bahwa tempe merupakan jenis bahan makanan yang kaya akan protein. Pada saat pretest, sebanyak90.9\% sasaran menyetujui pernyataan tersebut dan terdapat $9.1 \%$ sasaran yang tidak setuju. Namun, setelah diberi penyuluhan, seluruh sasaran ternyata telah mengetahui bahwa tempe adalah makanan yang kaya akan protein. Hal ini dapat dilihat dari hasil post-test bahwa $100 \%$ sasaran menyatakan tempe kaya akan protein (Gambar 3).

Meskipun ditumbuhi oleh kapang Rizhopus oryzae sp., tempe adalah makanan yang aman dikonsumsi meskipun dalam keadaan mentah atau tidak mengalami proses pengolahan. Sebelum ditambah kapang, kedelai terlebih dahulu agar jaringan kedelai menjadi lunak dan basah sehingga mudah ditumbuhi oleh kapang. Oleh sebab itu, tempe sebenarnya adalah makanan yang siap konsumsi, meskipun tidak mengalami pengolahan.

Penggorengan tempe dapat menurunkan jumlah dan mutu zat gizi yang ada dalam tempe. Karena itu, tempe sebaiknya mendapatkan proses pengolahan yang minimal, terutama pengolahan panas, seperti digoreng. Pada kegiatan pengabdian pada masyarakat ini, sebelum penyuluhan dilakukan, terlebih dahulu ditanyakan kepada sasaran apakah tempe sebaiknya digoreng agar kapang yang berwarna putih pada tempe mati. Sekitar Jahe merupakan salah satu jenis rempah asli Indonesia yang banyak dimanfaatkan $40.9 \%$ sasaran menyatakan tempe sebaiknya tidak digoreng agar zat gizi yang diperoleh lebih optimal. Setelah diberi penyuluhan, persentase sasaran yang menjawab tempe sebaiknya tidak digoreng meningkat menjadi $100 \%$. Ini menunjukkan bahwa seluruh sasaran dapat memahami informasi yang disampaikan oleh narasumber, bahwa tempe lebih baik tidak digoren (Gambar 3).

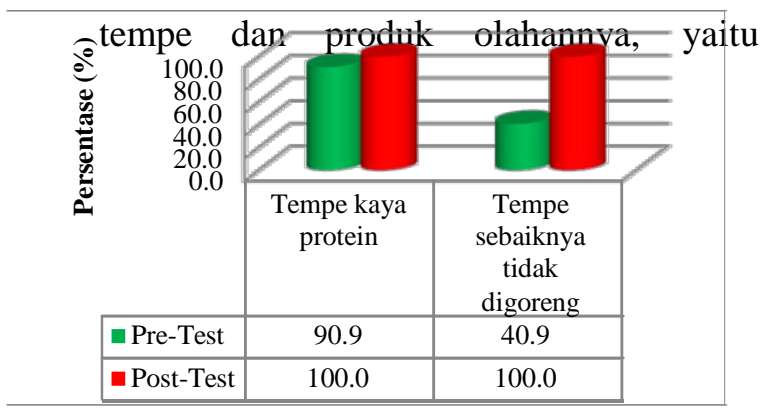

Gambar 3. Sebaran Sasaran berdasarkan Pendapat tentang Kandungan dan Cara Pengolahan Tempe

Selain jumlah protein yang tinggi, kualitas protein pada tempe juga tinggi karena protein tempe mudah dicerna oleh enzim protease yang ada dalam tubuh. Baik pada pre-test maupun post-test, persentase sasaran yang memberikan jawaban benar terhadap pernyataan bahwa protein tempe memiliki kualitas yang sama dengan daging meskipun harganya murah adalah sama, yaitu 95.5\% (Gambar 4).

Karena memiliki kualitas protein yang tinggi, maka tempe dapat diberikan kepada bayi dan anak-anak, meskipun tempe ditumbuhi oleh kapang Rizhopus oryzae sp. Sebanyak 77.3\% sasaran menyatakan setuju dengan pernyataan tersebut sebelum diberikan penyuluhan (pretest). Setelah mendapatkan penyuluhan, persentase sasaran yang menyetujui pernyataan bahwa tempe cocok untuk bayi dan anak-anak meningkat menjadi 95.5\%. Hal ini memperlihatkan adanya pengaruh dari penyuluhan dalam meningkatkan pengetahuan sasaran tentang kandungan dan mutu gizi dari tempe, sehingga terjadi peningkatan persentase sasaran yang dapat menjawab pertanyaan dengan benar.

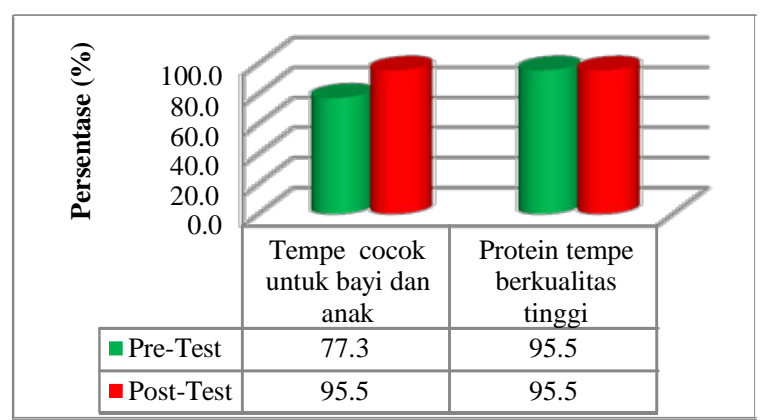

Gambar 4. Sebaran Sasaran berdasarkan Pendapat tentang Kualitas Tempe dan Kecocokan Tempe bagi Bayi dan Anak-anak 


\section{Tempe}

Minuman sari tempe adalah minuman yang dibuat menggunakan bahan baku tempe dengan cara mengambil sari dari tempe menggunakan air panas. Cara pembuatan minuman sari tempe sebenarnya sangat sederhana, tetapi tidak semua orang dapat membuat minuman tersebut.

Pada saat pre-test, sebanyak 77,3\% sasaran mengetahui bahwa sari tempe dapat dibuat dengan menggunakan air panas. Persentase tersebut menjadi meningkat pada saat post-test, yaitu 90,9\%. Peningkatan ini terjadi karena semakin banyaknya sasaran yang mengerti cara pembuatan minuman sari tempe setelah mendapatkan penyuluhan dari narasumber.

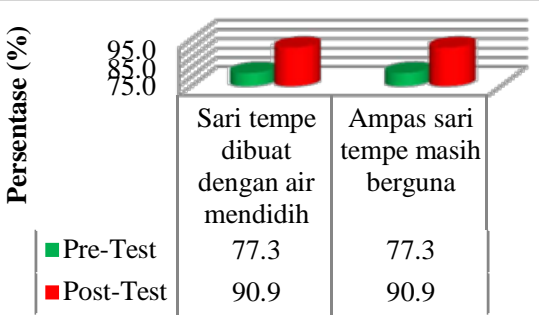

Gambar 5. Sebaran Sasaran berdasarkan Pengetahuan tentang Pembuatan Sari Tempe dari Air Mendidih dan Ampas Tempe

Sari tempe dibuat dari hasil pemisahan sari tempe dengan hancuran tempe menggunakan air panas. Ampas hasil pemisah-an sari tempe dengan hancuran tempe sebenarnya masih mengandung gizi dan serat makanan yang bermanfaat bagi kesehatan. Jadi, ampas tersebut dapat digunakan sebagai bahan baku untuk pembuatan produk pangan, seperti kue basah.

Meskipun mengandung banyak gizi, tidak semua sasaran mengetahui bahwa ampas pembuatan sari tempe masih dapat digunakan sebagai bahan baku produk olahan lainnya. Berdasarkan hasil survei pada saat pre-test diketahui bahwa persentase sasaran yang menyatakan ampas sari tempe masih berguna adalah sebanyak 77,3\%. Persentase tersebut karena sasaran mendapatkan pengetahuan tentang kandungan gizi ampas sari tempe pada saat penyuluhan.

Tepung tempe merupakan salah satu bentuk produk awet dari tempe. Pengubahan tempe basah menjadi bentuk tepung dapat meningkatkan variasi olahan dari tempe karena tepung tempe dapat digunakan sebagai tambahan atau bahan baku untuk pembuatan berbagai produk olahan. Tepung tempe dapat dijadikan sebagai bahan baku untuk pembuatan kue basah atau kue kering dengan tingkat penerimaan yang baik. Kue yang dibuat dari tepung tempe juga mengandung gizi yang tinggi.

Ketika ditanyakan kepada sasaran tentang penggunaan tepung tempe sebagai bahan baku pembuatan kue, pada saat pre-test, sebanyak 81,8\% sasaran menyatakan tepung tempe cocok dijadikan sebagai bahan baku pembuatan kue. Persentase tersebut meningkat menjadi 100\% pada saat post-test. Ini menunjukkan bahwa seluruh sasaran dapat memahami kegunaan tepung tempe dalam pengolahan makanan, sebagaimana disampaikan oleh narasumber pada waktu penyuluhan.

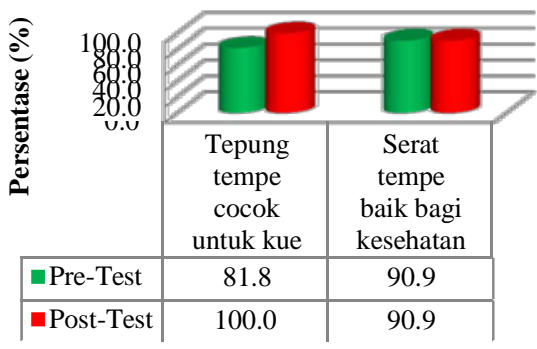

Gambar 6. Sebaran Sasaran berdasarkan

Pengetahuan tentang Penggunaan Tepung

Tempe untuk Kue dan Manfaat Serat

Tempe bagi Kesehatan

Selain mengandung protein, tempe juga kaya akan serat. Kandungan serat tepung tempe adalah sekitar 1,4 g/100 g (Astuti, 1982). Serat makanan merupakan komponen dari tanaman, termasuk di dalam tepung tempe, yang tidak dapat dicerna oleh sistem pencernaan manusia, karena manusia tidak memiliki enzim untuk mencerna serat tersebut. Serat makanan memiliki banyak manfaat bagi ksehatan, antara lain dapat 


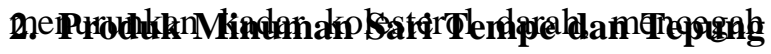

konstipasi, menyehatkan usus besar sehingga terhindar dari penyakit kanker usus besar, divertikulosis, dan lain-lain.

Pengetahuan sasaran kegiatan pengabdian kepada masyarakat ini tentang manfaat serat bagi kesehatan dapat dinyatakan baik karena dari hasil survei dapat diketahui bahwa persentase sasaran yang menyatakan serat bermanfaat bagi kesehatan termasuk tinggi. Baik pada saat pre-test maupun post-test, persentase sasaran yang menyatakan serat tempe baik bagi kesehatan adalah sama, yaitu 90,9\%.

\section{B. Tingkat Pengetahuan tentang Minuman Sari Tempe dan Tepung Tempe}

Proses pembuatan minuman sari tempe dan tepung tempe pada kegiatan pengabdian kepada masyarakat ini dijelaskan oleh sejumlah mahasiswa yang dilibatkan pada kegiatan ini dalam bentuk demonstrasi. Penjelasan tentang proses pembuatan produk diberikan oleh mahasiswa bersamaan dengan demonstrasi pembuatan produk.

Minuman sari tempe dan tepung tempe yang dihasilkan dari kegiatan demonstrasi selanjutnya disajikan kepada seluruh sasaran untuk dicicipi dan dinilai secara inderawi. Untuk mengetahui respon sasaran terhadap minuman sari tempe dan tepung tempe yang dihasilkan, maka kepada sasarn diberikan angket yang berisi 10 pertanyaan seputar minuman sari tempe dan tepung tempe. Hasil penilaian inderawi dari sasaran tersebut dijelaskan di bawah ini.

\section{Konsumsi dan Produksi Minuman Sari Tempe dan Tepung Tempe}

Tempe merupakan makanan sumber protein berkualitas tinggi yang mudah didapat dan murah harganya. Karena itu, tidak heran jika tempe dikonsumsi oleh hampir semua kelompok masyarakat, mulai dari anak-anak hingga orang lanjut usia. Sebagian besar sasaran (85,7\%) menyatakan mengonsumsi tempe setiap hari, baik untuk diri sendiri maupun keluarga (Gambar 7). Alasan sasaran mengonsumsi tempe setiap hari adalah karena bergizi dan harganya murah.

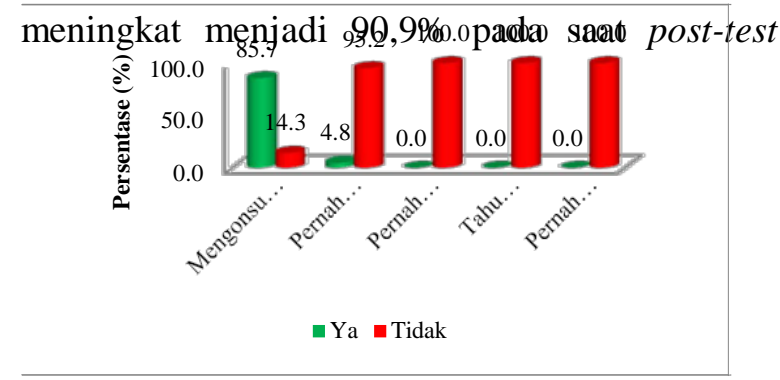

Gambar 7. Sebaran Sasaran berdasarkan Konsumsi dan Produksi Minuman Sari Tempe dan Tepung Tempe

Tempe yang dikonsumsi sasaran biasanya diolah menjadi lauk dengan cara digoreng atau dibacem. Hanya sekitar 4,8\% sasaran yang pernah mengolah tempe menjadi kue atau menjadikan tempe sebagai bahan baku pembuatan kue. Sisanya, yaitu 95,2\%, tidak pernah membuat kue dengan menggunakan tempe sebagai bahan baku. Hal ini disebabkan oleh kurangnya pengetahuan dan keterampilan sasaran tentang pengolahan tempe menjadi produk olahan.

Pembuatan minuman sari tempe sebenarnya dapat dilakukan dengan menggunakan teknologi sederhana. Karena kurangnya pengetahuan sasaran tentang cara pembuatan minuman sari tempe, maka pada saat survei dilakukan dapat diketahui bahwa tidak seorangpun (0\%) yang pernah membuat minuman sari tempe. Bahkan, semua (100\%) sasaran tidak tahu cara membuat minuman sari tempe tersebut dan tidak pernah pula membuat tepung dari tempe (Gambar 8).

Semua pengelola dan tutor PAUD yang mengikuti kegiatan pengabdian kepada masyarakat ini menyatakan bahwa mereka baru mengetahui adanya produk minuman sari tempe dan tepung tempe ketika mengikuti kegiatan pelatihan ini. Mereka juga menyatakan bahwa mereka tidak pernah membayangkan adanya produk minuman dari tempe karena tempe merupakan produk olahan hasil fermentasi kedelai oleh kapang.

\section{Tingkat Penerimaan Minuman Sari Tempe dan Tepung Tempe}

Minuman sari tempe dan tepumg tempe merupakan produk olahan tempe yang memiliki 
banyak manfaat, sebagai bahan baku untuk pembuatan produk olahan pangan lainnya ataupun manfaat bagi tubuh ketika dikonsumsi. Agar dapat diterima oleh para peserta pelatihan kegiatan ini, maka minuman sari tempe dan tepung tempe yang dihasilkan harus dinilai secara inderawi atau berdasarkan tingkat penerimaan oleh organ tubuh. Terdapat 3 aspek penilaian yang dilakukan sasaran terhadap minuman sari tempe dan produk olahan tepung tempe, yaitu rasa, warna, dan aroma.

Hasil penilaian inderawi terhadap minuman sari tempe oleh peserta pelatihan menunjukkan bahwa semua (100\%) sasaran menyukai minuman sari tempe (Gambar 9). Ini menunjukkan bahwa sasaran tidak terpengaruh oleh rasa tempe sebagai bahan baku minuman sari tempe yang sedikit langu, karena pada proses pembuatan minuman sari tempe ditambahkan gula dan perisa yang dapat menutupi rasa asal dari tempe.

Selain rasa, warna dari minuman sari tempe juga disukai oleh hampir semua peserta pelatihan. Sebanyak 95,2\% sasaran menyukai warna minuman sari tempe, dan hanya 4,8\% sasaran yang tidak menyukai warnanya.

Hal yang sama juga dijumpai pada aroma minuman sari tempe. Sebagaimana penerimaan terhadap warna, sebanyak 95,2\% sasaran juga menyukai aroma minuman sari tempe dan sisanya sebanyak 4,8\% saja yang tidak menyukainya (Gambar 8).

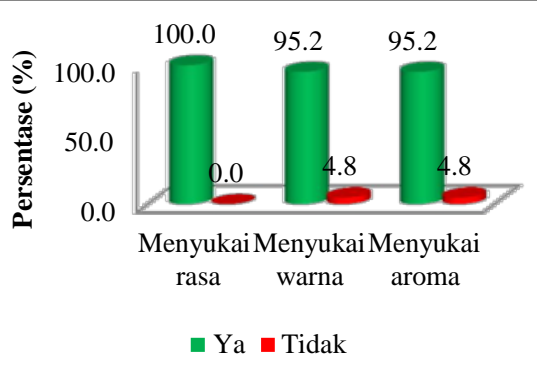

Gambar 8. Sebaran Sasaran berdasarkan Tingkat Penerimaan terhadap Minuman Sari Tempe

Tingkat penerimaan tepung tempe tidak didasarkan pada penerimaan sasaran terhadap produk olahan tepung tempe, tetapi berdasarkan penerimaan terhadap produk olahan tepung tempe. Pada pelatihan ini, tepung tempe diolah menjadi produk bola biskuit coklat (biscuit truffle), yaitu kue yang dibuat dari bahan hancuran biskuit, susu kental manis, tepung tempe kasar, dan meses. Hasil survei menunjukkan bahwa semua sasaran (100\%) menyukai rasa, warna, dan aroma dari produk bola biskuit coklat tempe yang dihasilkan (Gambar 9). Tidak satupun sasaran yang tidak menyukai produk olahan tersebut. Dari data ini dapat diketahui bahwa penambahan tepung tempe pada pengolahan produk pangan dapat diterima oleh masyarakat.

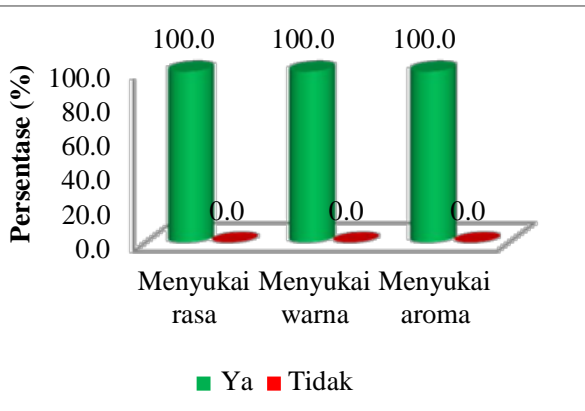

Gambar 9. Sebaran Sasaran berdasarkan Tingkat Penerimaan terhadap Bola Biskuit Coklat Tempe

\section{Tindak Lanjut}

Pada saat kegiatan pelatihan dan demonstrasi pembuatan produk minuman sari tempe, tepung tempe, dan produk bola biskuit coklat tempe selesai dilaksanakan, kepada para peserta pelatihan diberikan 3 pertanyaan yang berkaitan dengan tindak lanjut dari kegiatan pengabdian kepada masyarakat ini. Sekitar 95,2\% sasaran menyatakan bahwa produk olahan tempe merupakan produk yang dapat diberikan kepada anak-anak dan orang dewasa, sehingga mereka akan menindaklanjuti dengan keinginannya untuk membuat sendiri produk olahan tersebut, minimal untuk diberikan kepada anggota keluarga.

Proses pembuatan produk olahan tempe dinyatakan oleh $76,2 \%$ sasaran tidak sulit karena menggunakan teknologi sederhana yang bisa dilakukan di rumah. Walaupun masih ada sasaran yang menyatakan proses pembuatan produk olahan tempe sulit (23,8\%), tetapi para 
sasaran tersebut yakin bisa membuat produkproduk tersebut di rumah.

Para peserta pelatihan diminta pula untuk menilai kelayakan dari produk yang sudah dibuat untuk dijual di pasar. Hasil survei menunjukkan bahwa semua (100\%) sasaran pelatihan menyatakan produk olahan tempe, yaitu minuman sari tempe dan tepung tempe yang dihasilkan sangat layak untuk dijual.

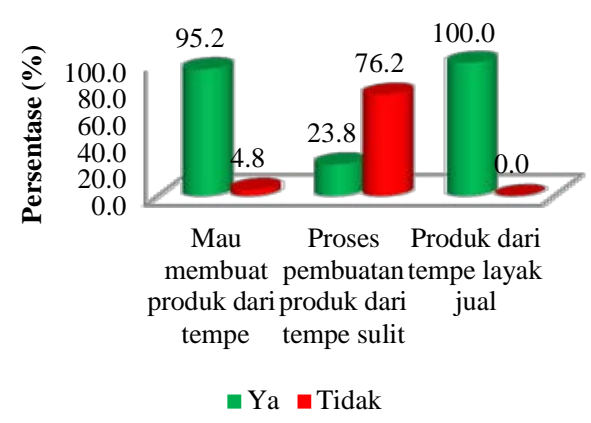

Gambar 10. Sebaran Sasaran berdasarkan Tindak Lanjut yang Dilakukan Sasaran setelah Mengikuti Pelatihan

\section{Kendala yang Dihadapi}

Ada beberapa kendala yang masih dijumpai pada pelaksanaan kegiatan ini, yaitu:

1. Terbatasnya jumlah peserta yang dapat mengikuti kegiatan ini karena dana untuk penyediaan bahan baku dan peralatan yang digunakan pada pelaksanaan kegiatan pengabdian kepada masyarakat ini juga terbatas.Sebagai akibatnya, kegiatan ini hanya dilakukan dalam bentuk demonstrasi dan bukan dalam bentuk praktik sendiri oleh setiap peserta.

2. Tidak ada monitoring terhadap perkembangan penguasaan keterampilan serta praktik pembuatan produk olahan tempe oleh peserta pelatihan setelah kegiatan pengabdian kepada masyarakat selesai dilakukan.

3. Belum adanya nota kesepakatan yang bersifat berkelanjutan (MoU) dengan PAUD Kuntum Melati Kampung Makasar Jakarta Timur, sehingga tidak ada kepastian untuk berlanjutnya kegiatan pengabdian kepada masyarakat ini di tempat yang sama pada tahun mendatang.

\section{KESIMPULAN}

Kesimpulan yang dapat diambil dari kegiatan penyuluhan ini adalah:

a. Kegiatan penyuluhan dan demonstrasi pembuatan minuman sari tempe, tepung tempe, dan produk olahan tepung tempe bagi pengelola dan tutor PAUD Kuntum Melati Kampung Makasar Jakarta Timur dapat meningkatkan pengetahuan sasaran dalam mengolah tempe menjadi produk olahan yang layak jual.

b. Motivasi dan semangat peserta untuk mengikuti kegiatan pelatihan dapat dinyatakan tinggi yang ditunjukkan oleh tidak adanya peserta yang meninggalkan kegiatan hingga kegiatan berakhir.

c. Kegiatan penyuluhan dan demonstrasi ini dapat mengubah sikap dan keterampilan sasaran dalam mengolah tempe menjadi produk yang memiliki nilai ekonomi tinggi.

\section{DAFTAR PUSTAKA}

Prasetyo, S., dan A.S. Cantawinata. 2010. Pengaruh Temperatur, Rasio Bubuk Jahe Kering dengan Etanol, dan Ukuran Bubuk Jahe Kering terhadap Ekstraksi Oleoresin Jahe (Zingiber officinale, Roscoe). Seminar Rekayasa Kimia dan Proses, Jurusan Teknik Kimia Fakultas Teknik Universitas Diponegoro Semarang, 4-5 Agustus 2010.

Albertine, A, A. Darda, R. Inaryani, BN. Kusuma, dan M. Arsyad. 2008. Tepung Tempe sebagai Sumber Protein Nabati yang Ekonomis. http://repository. ipb.ac.id/handle/123456789/33708

Kasmidjo, R.B., 1990. Tempe. Pusat Antar Universitas Pangan dan Gizi. Universitas Gadjah Mada. p. 1- 95.

Susanti, I., 1992. Mempelajari Pembuatan Minuman Padat Gizi dari Tempe. IPB, Bogor. 